\title{
Are EFL Writers Motivated or Demotivated by Model Texts and Task Repetition? Evidence from Young Collaborative Writers
}

\author{
AMPARO LÁZARO-IBARROLA* \& IZASKUN VILLARREAL \\ I-COMMUNITAS Institute for Advanced Social Research \\ Public University of Navarre (Spain)
}

Received: 02/02/2021. Accepted: 05/09/2021.

\begin{abstract}
Studies on multi-stage writing tasks with adults and children have shown that model texts and task repetition aid language acquisition, especially when learners work in collaboration. However, these studies have not included measures of task motivation, which is vital in young learners (YLs) and could help develop a more comprehensive understanding of task effectiveness. The present study analyses task motivation in 24 EFL YLs writing in pairs during three sessions divided into a model group (MG) and a task repetition group (TRG). Results show that students' task motivation is high in general but declines in the MG while it is maintained in the TRG. As for the motives, working together is the main reason students give to justify their positive scores. These results complete previous knowledge about models and TR, reinforce the value of collaborative writing and encourage the inclusion of motivation measures in task-based research.
\end{abstract}

KEYWORDS: Model texts; Collaborative writing; Task repetition; Task motivation; Child learners; EFL.

\section{INTRODUCTION}

The impact of task motivation (Al Khalil, 2011; Dörnyei \& Kormos, 2000; García Mayo, 2018; MacIntyre \& Serroul, 2014) on second language acquisition (SLA) has been recently brought into the spotlight. Task motivation has been recognized to be context-bound and to affect students' outcomes (Al Khalil, 2011; Dörnyei, 2002). In fact, perceived language learning affordances seem to be key when determining achievements (e.g., Al Khalil, 2011; Dörnyei, 2002; Dörnyei \& Kormos, 2000; Kormos \& Dörnyei, 2004) and, therefore, examining what fuels or depletes motivation seems necessary. Likewise, introducing tasks that motivate students in the classroom is vital (Robinson, 2011) and so should be the measurement of

\footnotetext{
*Address for correspondence: I-COMMUNITAS Institute for Advanced Social Research, Public University of Navarre, Spain; e-mail: amparo.lazaro@unavarra.es

(C) Servicio de Publicaciones. Universidad de Murcia. All rights reserved. 
motivation in task-based research, especially in the case of young learners (YLs) who, still unaware of the learning demands, tend to deem activities on the amount of pleasure they get from them (Kiss \& Nikolov, 2005).

In the field of writing tasks, studies on collaborative writing $(\mathrm{CW})$, model texts or task repetition have mainly focused on the linguistic benefits they bring about but have also made some general claims about their motivational value. Thus, CW (Villarreal \& Munarriz-Ibarrola, 2021; Storch, 2005) or the provision of corrective feedback via model texts have been considered to be positive for student's motivation. On the contrary, mere task repetition has often been described as boring and demotivating (Nitta \& Baba, 2014).

Within this context, the present study analyses the task motivation data in a group of students from a larger project on the effects of CW and different types of feedback with YLs. In the present work, we repyort on task motivation in two groups of YLs working in pairs in the same school: a model group (MG) and a task repetition group (TRG). Our results could help to acquire a more thorough understanding of the potential of these tasks with YLs while also helping to further understand task motivation. More generally, we also contribute to a better understanding of SLA in YLs who constitute the fastest growing and largest population of language learners in the world (Enever, 2018), yet still under-researched.

\section{LITERATURE REVIEW}

\subsection{Task motivation}

While general motivation has attracted a great deal of attention in SLA (Gardner, 1985), taskmotivation stays a less known construct. In the last decade, researchers have emphasized the dynamic nature of motivation and the difference between general motivation towards learning a language and task motivation, that is, the specific motivational dispositions that students can display towards a given task (Dörnyei \& Kormos, 2000).

In a seminal and eye-opening piece of research that attempts to amplify the lens through which we conduct task-based language teaching (TBLT) research, Dörnyei and Kormos (2000) explain that, to fully understand the performance and outcomes of students on a given task, we need to also examine factors that are not linguistic or cognitive but play an important role in how the task is resolved. These authors claim that including measures of motivation as well as of other affective factors will result in a "fruitful extension of existing task-based research paradigms" (Dörnyei \& Kormos, 2000: 275). 
L2 motivation theory has largely drawn on psychological theories of the self (see Dörnyei, 2020 for its development). However, and until relatively recently, the developments only included two main dimensions depending on whether the students had a mere will to learn the language (integrative motivation) or whether they were motivated by a specific purpose (instrumental motivation). Taking a step forwards, Dörnyei (2009) included a new dimension: the learning context. These three components were captured in his theory of the L2 Motivational Self System (L2MSS), which included (i) the "ideal L2-self", referring to person's hopes and dreams as a language learner; (ii) the "ought-to L2-self", referring to who the learner feels s/he should become in relation to external demands; and (iii) the L2 learning experience, which refers to the immediate learning context and the students' attitudes towards it.

In line with this, task motivation is defined as a multi-faceted and dynamic complex of motivational influences and task engagement is assumed to be a prerequisite for successful L2 learning (Dörnyei, 2019). In fact, empirical studies using the L2MSS have often concluded that the L2 learning experience was the "most powerful predictor of motivated behaviour" (Dörnyei, 2019, p. 22). However, this broad concept of experience has not been successfully translated into specific and measurable terms although most researchers have employed short scales with few items to measure it. To improve the measurement and conceptualization of the L2 learning experience, Dörnyei (2019) proposes to adopt an engagement-specific perspective and defines the L2 Learning Experience as the perceived quality of the learners' engagement with various aspects of the language learning process. The word "engage" offers the possibility to build the phrase "to engage with TARGET" (Dörnyei, 2019: 25), which can be broken down into more specific facets, such as the learning tasks.

Within this context, the study of task motivation in YLs seems worthy of attention. The inclusion of the context as a key element goes in line with findings from studies on YLs, which reveal a strong link between motivation and the school context (Muñoz, 2017; Nikolov, 1999) and encourages the inclusion of measures of task motivation. So far, the scant existing attempts suggest that course attitudes (Dörnyei \& Kormos, 2000; Kormos \& Dörnyei, 2004) and collaboration (Azkarai \& Kopinska, 2020; Calzada \& García Mayo, 2020; Imaz Agirre \& García Mayo, 2020; Kopinska \& Azkarai, 2020) positively affect young learners’ on-task motivation.

This has constituted a call to consider task motivation in empirical studies in the field of TBLT, as it is considered to be dynamic, context-bound (Al Khalil, 2011, 2016) and key to successful task performance (Dörnyei \& Kormos, 2000; Julkunen, 2001). More specifically, task motivation seems to be the trigger or pre-condition to get students engaged (Kormos \& Dörnyei, 2004) and to sustain this engagement (Al Khalil, 2011). Of course, once the driving force of task motivation has set students into motion other factors are also necessary to 
determine the quality of students' outcomes (Kormos \& Dörnyei, 2004). Some authors also explain that students' task motivation will not only affect their performance on a particular task but also their general motivation and, ultimately, their learning process (Al Khalil, 2011; Robinson, 2011). Therefore, classroom practices should place the choice of motivating tasks at the core of their lesson plans and this should be particularly taken into account with YLs, as their performance greatly improves when they do activities that they enjoy (Kiss \& Nikolov, 2005). How other conditions such as collaboration, task repetition and model revision interplay with task motivation seems, therefore, worth investigating.

\subsection{Task motivation and collaboration}

In spite of the acknowledged value of task motivation, not many studies in task-based research have attempted to measure it. Most research including this variable has been conducted in the context of collaborative tasks. This has been the case because many of the learning activities in language lessons are performed either in pairs or small groups (Dörnyei \& Kormos, 2000; Fernández Dobao, 2012) and, on the other hand, because recent research has emphasized the potential of collaborative oral and written tasks to offer learning opportunities and to motivate students (Azkarai \& García Mayo, 2016; Azkarai \& Kopinska, 2020; Kim, 2015; Kim, Choi, et al., 2020; Storch, 2011; Villarreal \& Munarriz-Ibarrola, 2021). As motivation is dynamic (Dörnyei, 2002), adopting a dynamic approach to motivation entails addressing temporality directly and explicitly to capture its fluctuations (MacIntyre \& Serroul, 2014). When working in dyads, this dynamic nature of task motivation needs to be negotiated and co-constructed, that is, in a dyad affect is co-constructed and the perceptions of each individual can "become a powerful motivational conduit" (Dörnyei, 2019: 58) and affect the joint performance (Dörnyei, 2002; Kormos \& Dörnyei, 2004).

In the context of oral data, Dörnyei and Kormos (2000) measured task motivation in a group of young (ages 16-17) Hungarian EFL learners performing oral argumentative tasks in pairs in their L1 and in English. They found that when the learners' motivation was higher they were able to produce more language (Dörnyei, 2002; Dörnyei \& Kormos, 2000; Kormos \& Dörnyei, 2004). Dörnyei and Kormos (2000) concluded that affective (motivational) factors are co-constructed and dynamic and greatly impact the learners' language output. These factors should, therefore, be considered when task-based research is conducted so that the efficiency of a task can be studied in a more holistic and integrated manner.

Bearing this in mind, several studies with adults and oral data have introduced measures of motivation usually by means of pre and/or post-task questionnaires of different kinds (AlKhalil, 2016; Julkunen, 2001) and even occasionally by making attempts to include duringtask measures (Poupore, 2013). What's common to the findings of these studies is that 
motivation varies widely, not only when comparing participants but also when comparing pre and post-task scores and motives.

In the context of collaboration and writing, Villarreal and Munarriz-Ibarrola (2021) examined (among other factors) the motivation of pairs, groups of three and individual writers in a group of adolescent EFL learners (ages 12-13). The authors clearly identified that working together was a powerful motivating force in this group and collaboration was shown to spur motivation for writing. Learners highly valued collaboration for its language learning value.

In a study with slightly younger EFL learners (11-year-olds), Imaz Agirre and García Mayo (2020) analysed the influence of the pair formation method (self-selected or teacherselected) on task motivation using a pre and post-task motivation thermometer on which students had to choose a score and a motive (the same thermometer will be used in the present study). The students performed an oral task and a task that combined the oral and written modalities. These authors did not find significant motivational differences related to pairing or task modality but they did find that all students showed a significant upward trend in the posttask motivation scores. As for the motives, while students in teacher-selected pairs chose reasons related to the task itself to justify their scores, the self-selected ones opted for social explanations, such as the fact that they enjoyed working with the pairs. Similarly, Calzada and García Mayo (2020) administered motivation questionnaires to a group of Spanish EFL children (ages 11-12) completing writing tasks in pairs and small groups at their school. Their results show that the children had a positive attitude towards L2 writing, liked the collaboration and also deemed the blend of the written and oral mode as beneficial.

Of greater relevance for the present study are the findings by Azkarai and Kopinska (2020) and Kopinska and Azkarai (2020). These authors measured general as well as task motivation in Spanish EFL learners (aged 11-12) who performed dictogloss tasks either individually and in pairs (Kopinska \& Azkarai, 2020) or individually (Azkarai \& Kopinska, 2020). Their results revealed positive dispositions towards the dictogloss task, even more positive attitudes towards collaboration and consistently higher scores at post-task (vs. pretask) (Azkarai \& Kopinska, 2020; Kopinska \& Azkarai, 2020). Also, the positive attitude of the pair writers was maintained while that of the individual writers fluctuated more (Kopinska \& Azkarai, 2020).

When considered together, these pieces of research provide support to the idea that motivation is co-constructed by task participants also among YLs (Azkarai \& Kopinska, 2020; Dörnyei, 2002). In addition, these studies help to complete the results from previous research on CW: we knew that students writing in collaboration generate valuable language-related episodes and produce drafts of better quality (Storch, 1999, 2005, 2011; Villarreal \& MunarrizIbarrola, 2021; Wigglesworth \& Storch, 2009). Now, we also know that CW is motivating for most students, which could partly explain the advantages of collaborative writers in terms of 
their linguistic products. Further research is therefore needed on different writing tasks to better understand the impact of task motivation.

\subsection{Task repetition and motivation in the context of writing}

Task repetition (TR) is known to have great potential for language acquisition. When repeating an oral task, learners' attention can shift from meaning to form and the product can be improved (Bui et al., 2018; Bygate, 1996; Bygate \& Samuda, 2005). In the context of writing, however, research on TR is still scarce (Manchón, 2014a; Sánchez, 2018). Drawing on the distinction between internal and external TR defined by Bygate (1996) for oral tasks, Manchón (2014b) describes internal TR as a type of repetition that constitutes an integral part of task completion and external TR as a type of repetition that is externally imposed by the task instructions. Manchón (2014b) further divides external task repetition into two: tasks whose repetition follows from the processing of some type of feedback (external TR with WCF) and tasks whose iteration is a mere repetition of the previous output (external TR without WCF). In recent years, external exact TR with and without feedback has come to the forefront of writing research thanks to its potential to improve written drafts and offer learning opportunities, in particular, with learners writing in collaboration, as students can deliberate, give feedback to each other and write better texts (Storch, 2013 for a summary).

Thus, several empirical studies focusing on external TR without the provision of feedback have proved the potential of repeating the exact same writing task several times to improve the written products of adults (Amiryousefi, 2016; Kim, Kang, et al., 2020) and children (Hidalgo \& Lázaro-Ibarrola, 2020; Lázaro-Ibarrola \& Hidalgo, 2021), although the specific learning outcomes reported by different studies are far from homogeneous. For instance, regarding adult populations, Nitta and Baba (2014) conducted a unique piece of research on the effects of mass TR with forty-six first-year Japanese university students. Over thirty weeks each student had to write a composition per week. The results revealed very limited TR effects while task-type repetition did have a marked effect in terms of lexical and grammatical aspects. In another relevant study, Sánchez et al. (2020) analysed the production of 29 (16 high-school and 13 university) Spanish EFL learners completing a decision-making task twice, either orally or in writing and did not find any positive effects in the areas of lexical complexity and accuracy. What is more, they found a detrimental effect in the area of syntactic complexity, reflected in a smaller rate of global subordination, and which was especially important in the writing group. Sánchez, et al. (2020) highlight how the disparity of results confirms the difficulty in predicting the effects of TR, already announced by Samuda and Bygate (2008), as well as the dependency of effects on different variables (modality, proficiency, task, age, etc.). In sum, these mixed results per se encourage more research on the 
topic. As for YLs, very few studies have focused on external exact TR without the provision of WCF so far. Hidalgo and Lázaro-Ibarrola (2020) examined the compositions of 10 pairs of primary school EFL learners (aged 12) who wrote the same text in response to the same picture prompt three times over a three-week period. The compositions improved with repetition when measured by holistic ratings (although not when measured by CAF measures). Similarly, Lázaro-Ibarrola and Hidalgo (2021) found some benefits in terms of holistic ratings in a same TR group of YLs of English in primary school but not in a procedural repetition group.

In terms of task motivation, it is interesting to mention the study by Kim, Choi et al. (2020), as these authors introduced a research question specifically addressing students' perceptions in their study. Kim, Choi et al. (2020) examined the effects of TR and indirect synchronous WCF during collaborative writing on the quality of students' drafts and on the learning of Korean grammar with fifty-four university students learning Korean as a foreign language completing a pretest, two collaborative writing tasks, and two post-tests. In terms of linguistic outcomes, the findings identified a positive impact of TR on fluency, a negative impact of synchronous WCF on fluency, and no impact on the grammatical features. As for students' perceptions, Kim, Choi et al. (2020) made the students complete a survey using a Likert scale and including 10 items revolving around the following categories: perceived task difficulty, satisfaction with task performance, enjoyment, motivation for future tasks, perceived learning opportunities and the effectiveness of task repetition. They also included three openended questions. The findings showed that TR positively impacted students' perceptions of task performance and that learners found the task was less difficult and more enjoyable. Also, the participants expressed that they were more satisfied with their own task performance the second time that they performed the task.

From a pedagogical point of view, the repetition of a task is common practice in the language classroom (Fernández-Dobao, 2012; Lázaro-Ibarrola \& Hidalgo, 2017). Nevertheless, some teachers might be reluctant to use TR in the context of writing because students could perceive it as tedious (Hawkes, 2009), especially if there are several repetitions. For instance, in the above-reviewed study by Nitta and Baba (2014), the students repeat the same task and topic only twice (although the same task type was repeated thirty times) because the authors believe that "exactly repeating the same task and the same topics over a long period can be expected to reduce student motivation" (Nitta \& Baba, 2014: 115). Exploring task motivation would thus be interesting to confirm or reject this belief and to encourage or discourage the use of TR with written drafts. 


\subsection{Model texts and motivation in the context of writing}

The provision of feedback is vital in the writing modality and helps define the distinctive nature of TR in connection to the writing mode. As explained above, Manchón (2014b) divides external TR into two types depending on whether it is a mere repetition of the output or a repetition accompanied by WCF. In the context of multi-stage tasks, the provision of WCF creates a TR cycle in which students write, revise with feedback and rewrite. In spite of the scarce research conducted so far, several authors have emphasized the potential of combining the effects of TR and feedback (Amelohina et al., 2020; Ellis, 2009; Manchón, 2014a,b). In addition to this, students want and expect WCF (Ferris \& Hedgcock, 2014), their preferences seem to mediate the effectiveness of the different types (McCargar, 1993; Schulz, 2001) and these preferences have been shown to vary widely from student to student (Kim \& Nassaji, 2018), which reveals the need to measure task motivation when the effectiveness of WCF is assessed.

Among the different types of WCF, this paper will focus on the provision of model texts. Multi-stage writing tasks providing feedback via model texts have been the object of several studies with adults (Hanaoka, 2007; Hanaoka \& Izumi, 2012; Kang, 2020) and children (Cánovas Guirao et al., 2015; Coyle \& Cánovas Guirao, 2019; Coyle et al., 2018; Coyle \& Roca de Larios, 2014, 2020; Lázaro-Ibarrola, 2021; Luquin \& García Mayo, 2020, 2021) and their value for the classroom in terms of learning potential and feasibility has been well established. Research regarding its impact on task motivation, however, is still in its infancy, with very few studies considering measures of motivation in connection to model texts (García Mayo \& Loidi Labandibar, 2017; Yang \& Zhang, 2010).

One first attempt to consider motivation in a multi-stage writing task was the study conducted by Yang and Zhang (2010). These authors examined the effectiveness of model texts, accompanied by reformulations and pair discussions, in a three-stage task. Their students $(n=10)$ were enrolled in an EFL writing class in a Beijing university and, although motivation was not part of the research questions, the learners were interviewed after class to elicit their attitudes towards the task in an attempt to obtain information that could help understand the learning outcomes. In relation to students' attitudes, the authors reported that the students appreciated having access to a native model text for a broad range of language input. More recently, another study considering motivation with model texts was conducted by García Mayo and Loidi Labandibar (2017). These authors investigated what Basque-Spanish EFL learners $(n=60)$ in secondary school (aged 13 and 16) noticed during a three-stage writing task in which model texts were used. Their study included the use of a questionnaire at the end of the three stages to measure the learners' attitude towards writing and modelling and they also included a research question related to this matter (the fourth of four research questions). Their 
findings showed that the learners' attitudes were quite negative in general. However, the students with more positive dispositions were able to incorporate more elements from the models in their revisions. Based on this positive correlation the authors encourage the inclusion of more sophisticated measures of motivation in future studies.

As for the collaboration, WCF via models has been usually implemented as a threestage writing task and very frequently with students working in pairs (Yang \& Zhang, 2010), especially when YLs have been the participants (Cánovas Guirao et al., 2015; Coyle \& Roca de Larios, 2014, 2020): first, students write a draft, second, they are given a model to compare to their original writing and, third, they are asked to rewrite their draft trying to incorporate features from the model. Researchers have found that students incorporate mainly lexical items from the models and that they are able to improve their subsequent drafts, however, except for the study by Yang and Zhang (2010) reviewed above, no measures of task motivation have been included in any of these studies.

In sum, the importance of task motivation is clear but research on multi-stage writing tasks with models or TR has not included task motivation among the variables scrutinized, therefore, our study will help create a body of knowledge on task motivation in multi-stage writing tasks and shed light on previous findings from models and TR by investigating students' task motivation in each of the stages of writing. Results will be of interest for both SLA research and language teachers.

\section{THE STUDY}

\subsection{Research Questions}

The present study analyses the pre and post-task motivation scores and the motives of 12 pairs of CLIL Primary learners writing collaboratively in two groups, a model group (MG) and a task repetition group (TRG). The following research questions for both groups guided this study:

a) Do motivation scores change from pre-task to post-task in each of the three sessions?

b) Do pre-task and post-task motivation scores change from session to session?

c) What motives do learners choose to describe their scores in each session?

Based on the literature review presented above we can formulate some hypotheses. Regarding motivational variation before and after each task, a positive upward trend in the two groups is expected at post-task (Imaz Agirre \& García Mayo, 2020; Kopinska \& Azkarai, 2020). As for the TRG, a mere repetition of the task might decrease students' motivation (Nitta $\&$ Baba, 2014). The lack of investigations including participants executing three iterations of (c) Servicio de Publicaciones. Universidad de Murcia. All rights reserved.

IJES, vol. 21(2), 2021, pp. 29-55 Print ISSN: 1578-7044; Online ISSN: 1989-6131 
the same written task, however, prevents any realistic expectation of the motivational effect of TR. Finally, following previous studies (Azkarai \& Kopinska, 2020; Calzada \& García Mayo, 2020; Imaz Agirre \& García Mayo, 2020; Kopinska \& Azkarai, 2020) social justifications might be the most frequently selected motives.

\subsection{Context and participants}

The study was conducted in a state school in Spain over a period of 5 weeks. The participants were 24 CLIL children in the $5^{\text {th }}$ course of Primary Education (aged 10-11) belonging to two classes. The school made frequent use of cooperation and group work as they mainly taught via projects in all school subjects. This means that pair work was common but, as the teachers explained, the students were not used to writing in pairs or to comparing their drafts to model texts. Also, the students had never been asked to assess their own level of task motivation. In view of this situation, and to make sure that students were able to perform the task satisfactorily, their teacher conducted a similar task with them and explained what they had to do during one school lesson. In this lesson, all students worked in pairs and had to write a draft and compare it to a model using a set of pictures. Also, they were asked to fill the thermometers choosing a score and a motive for each of the stages.

The study was conducted in two intact classes in their penultimate year of Primary Education with a total of 32 students. The proficiency level of the students was measured with the Cambridge English Flyers test (UCLES, 2019). Based on the results, six participants from the two classes where data were collected were eliminated from the study either because their language abilities were considered too high (above 8.5) or too low (below 3.5). A normality test determined that the Flyers test scores in the two groups were normally distributed and a Ttest revealed that there were no statistically significant differences between the two groups for the reading and writing scores $(\mathrm{t}=-.342 ; \mathrm{p}=.735)$, listening scores $(\mathrm{t}=-.433 ; \mathrm{p}=.669)$ or mean level test scores $(\mathrm{t}=-.401 ; \mathrm{p}=.692)$. Consequently, the division into the model $(\mathrm{MG}, \mathrm{n}=12,6$ pairs) and TR groups (TRG, n=12, 6 pairs) was determined at random. Also, two students did not fill in the motivation questionnaire and were also eliminated. Thus, our final pool of participants consisted of 24 students, 12 dyads, with a level test mean of 5.8 (SD 1.5) in one class and 5.6 (SD 1.6) in the other.

\subsection{Materials}

The instruments used for data collection were two motivation thermometers (see Appendix A), based on Al Khalil $(2011,2016)$ and identical to the ones used in recent studies with YLs of 
EFL (Azkarai \& Kopinska, 2020; Imaz Agirre \& García Mayo, 2020; Kopinska \& Azkarai, 2020).

The thermometers included a 0-10 score scale to rate students' dispositions. Zero represented the lowest possible score, while 10 represented the highest. To detect motivation variations, students were asked to choose a score from the thermometer before the task, to grasp their initial disposition, and another score once they had finished the task.

Also, when they finished each task, students were asked to choose a reason for their scores from a 12-item list. Following Kim, Choi et al. (2020), the items were grouped into three broad categories: (i) perceived task difficulty, (ii) perceived learning opportunities and (iii) enjoyment. In our study, the category referred to "enjoyment" included items referred to general enjoyment, enjoyment in relation to the task, enjoyment in relation to doing a task in English and, finally, enjoyment in relation to the collaboration (operationalized here as "working with a peer"). The list of items and their connection with these categories can be seen in Appendix B. A list of motives to choose from was provided because the teachers thought that it could be too challenging for the students otherwise, as they were still very young and might not be able to write about their motives. Also following the teachers' advice and to prevent misunderstandings, the motives in the thermometers were in the students' L1 (Luquin \& García Mayo, 2020).

\subsection{Procedure}

Data were collected in three sessions with a week interval between them. In the three sessions, the students in the MG and TRG worked in pairs, the same pairs were maintained in all sessions, and all sessions lasted 40 minutes. Matching proficiency pairs were made based on the Flyers test scores and with the help of the school teacher taking into account personal relationships in order to make sure they were able to work together.

In session 1, all the students performed the same task. They were given a picture story (see Appendix C) and were asked to look at it carefully and to write a composition describing what they could see in the pictures. They could not use dictionaries or ask the teacher for help. Before starting the task, they had to complete the thermometer by choosing a score that reflected their current motivation level. As soon as they finished, they were asked to complete another similar thermometer with a score and, also, with a motive describing their choice of a given score.

In session 2, the students in the TRG repeated the exact same procedure from session 1. On the other hand, the students in the MG were given two model texts to compare to their original writing and were asked to discuss the differences (see models in Appendix A). Two model texts were used to avoid mere copying from a single text and to increase learners' 
opportunities to find solutions in the models (Hanaoka, 2007). As in session 1, in both groups, the thermometers were administered before and after the task.

In session 3, the procedure of session 1 was repeated in both groups. Using the same picture prompt, the students wrote the composition again on a clean sheet, that is, they did not have access to their original drafts or to their notes (like Coyle et al. 2018; Coyle \& Roca de Larios 2020; Hanaoka \& Izumi 2012; Luquin \& García Mayo 2020, 2021; Roca de Larios \& Coyle, 2015; and unlike Coyle \& Roca de Larios, 2014; Hanaoka 2007). Our purpose was to avoid mere editing or copying from their original drafts. Again, the pre and post-task thermometers were administered and the post-task motives list too.

\subsection{Data analysis}

As every student filled in a thermometer score before and after each of the three tasks there were 144 motivation thermometers in total. As every student also chose a motive after each of the three tasks there were 72 motives in total. Thus, our analysis comprises the 144 motivation thermometers and the 72 motives the 24 students completed individually.

The dynamism or change in motivation was represented by the variation between total pre-task motivation and total post-task motivation (Poupore, 2013). Consequently, students pre-task scores (0-10) were contrasted with their post-task scores. To observe motivational changes over the various stages and iterations, students' motivational scores as well as motives were compared across tasks. To observe whether the MG and the TRG performed distinctly their scores and motives across drafts were contrasted. Finally, a general examination of individual pre- and post-task trajectories in the dyads will also be provided to complete our understanding of the general trends that emerged from our data.

As for the statistical analysis of the results, the data were introduced into an Excel spreadsheet and analysed using SPSS v27 for Windows. The data were not normally distributed and thus, non-parametric tests were used. The Friedman test was employed to identify differences across sessions and groups. Mann-Whitney U tests for independent samples were run to test for statistically significant differences between the MG and the TRG. To search for statistically significant differences within each group, Wilcoxon signed-rank tests for related samples were used instead. The confidence interval was established at $95 \%$.

\section{RESULTS AND DISCUSSION}

First, we present the results from the pre and post-task scores obtained from the thermometers in the MG and TRG groups in order to answer our two first research questions, which aimed 
to investigate whether motivation scores changed from pre-task to post-task in each of the three sessions (research question one) and also from session to session (research question two) in both groups.

Table 1 presents the scores students chose from the thermometers at pre and post-task in the three sessions.

Table 1. Mean results and standard deviations (SD) for the pre-task and after-task motivation thermometers by group in the three sessions.

\begin{tabular}{|c|c|c|c|c|c|c|}
\hline & \multicolumn{2}{|c|}{ Session 1 } & \multicolumn{2}{c|}{ Session 2 } & \multicolumn{2}{c|}{ Session 3 } \\
\hline \multirow{2}{*}{ MG } & Pre-task & Post-task & Pre-task & Post-task & Pre-task & Post-task \\
& 7.7 & 8.6 & 7.6 & 8.2 & 5.1 & 6.6 \\
& $(1.5)$ & $(0.9)$ & $(1.3)$ & $(1.2)$ & $(2.3)$ & $(1.7)$ \\
\hline \multirow{2}{*}{ TRG } & 7.8 & 9.5 & 8.8 & 9.4 & 9.1 & 9.2 \\
& $(1.6)$ & $(0.8)$ & $(1.3)$ & $(0.8)$ & $(1.1)$ & $(2)$ \\
\hline
\end{tabular}

Regarding pre-post task motivation shifts, in line with previous research (Azkarai \& Kopinska, 2020; Imaz Agirre \& García Mayo, 2020; Kopinska \& Azkarai, 2020), it is clear that the post-test scores are higher in the three sessions and in both groups, although the rise for the TRG was marginal in session 3 (Session 1: $\mathrm{MG}+0.9$, TRG +1.7; Session 2: MG 0.6, TRG +0.6; Session 3: MG +1.5, TRG +0.1). These increases suggest that the tasks were able to raise students' initial (pre-task) motivational disposition.

This upward trend was statistically significant in the MG in session $1(\mathrm{z}=2.598 ; \mathrm{p}=.009)$ and session $3(\mathrm{z}=-2.745 ; \mathrm{p}=.006)$ but not in the revision session, session $2(\mathrm{z}=-1,611 ; \mathrm{p}=.107)$. This lack of significance in session 2 seems to show that the comparison to the model texts did not raise their motivation so much, which points towards the motivational cost of model revision.

For the TRG, on the other hand, the rise in sessions 1 and 2 proved statistically significant $(\mathrm{z}=-2.694 ; \mathrm{p}=.007$ and $\mathrm{z}=-2.070 ; \mathrm{p}=.038$, respectively), while the third repetition in session 3 did not modify the scores $(\mathrm{z}=-.687 ; \mathrm{p}=.492)$. We argue that the lack of variation in the TRG in session 3 does not reflect boredom associated with TR effects as Nitta and Babba (2014) suggest, as a significant drop in students' motivation scores should have accompanied this tediousness. Rather we suggest that it might disclose some type of ceiling effect associated with the very high levels of motivation they already display at pre-task (9.1), which can hardly rise significantly given that they are so close to the top score.

If we look at the results for each pair and individual (see Appendix D), the shift at posttask is reflected in all the participants in both groups. There are only two exceptions in Session 2 (one student in pair 5 and one in pair 6 in the MG) and two in Session 3 (one student in pair 
2 in the MG and 1 student in pair 7 in the TRG). From these exceptions, the drop is of only one point except in the case of one student whose score decreases from 7 to 3 . When looking at the motives, this student is the only one who chose a negative one ("because I got bored"). By contrast, the other member of this pair maintained high motivation and offered a positive motive in the perceptions of collaboration category ("I liked to work with my peer"). This shows that, in spite of general trends, some individual trajectories can greatly differ within the group and within the pair, an issue in need of greater attention in research on task motivation.

The second research question deals with differences across sessions and groups. The Friedman tests ran evidenced significant differences across pre-task scores in the two groups (TRG: $\mathrm{x} 2=13,867 ; \mathrm{p}=.001 ; \mathrm{MG}: \mathrm{x} 2=14,973 ; \mathrm{p}=.001$ ) and in the post-tasks only in the MG $(\mathrm{x} 2=13,941 ; \mathrm{p}=.001 ; \mathrm{TRG}: \mathrm{x} 2=.615 ; \mathrm{p}=.735)$. Wilcoxon tests were then undertaken to see where the difference was. The MG showed a parallel attitude in the pre and post-task scores in the first and second sessions (pre-task $\mathrm{Z}=-.144, \mathrm{p}=.885$; post-task $\mathrm{Z}=-1.406, \mathrm{p}=.160$ ). This contrasts with the statistically significant variations observed between the pre and post-task scores in session 2 vs 3, and session 1 vs 3. (Session 2-3 pre-task $Z=-2.694$, p=.007; post-task $\mathrm{Z}=-2,410, \mathrm{p}=.016$; Session 1-3 pre-task $\mathrm{Z}=-2.829, \mathrm{p}=.005$; post-task $\mathrm{Z}=-2.848, \mathrm{p}=.004) . \mathrm{MG}$ students expressed they were significantly less motivated to write the text for the second time (session 3) after they had revised the models in session 2 (-2.5, 5.1 vs 7.6). They were also less enthusiastic before they wrote it for the second time than before they did it for the first time (2.6, 7.7 vs 5.1). The post-task results from the third session were also the most modest ones, although the increase was the biggest in the 3 sessions $(+0.9 ;+0.6 ;+1.5)$. Thus, in session 3 , the MG exhibits the lowest scores but the biggest motivation variation. It seems therefore that model text revision has a motivational cost, which might reflect that students are overwhelmed by the demands brought about by the model texts.

The TRG exhibited a very different behaviour. The TRG maintains very high and steady levels of pre and post-task motivation in the three repetitions. Only the pre-task motivation contrasts between session 1 and session $2(+1,7.8$ vs 8.8$)$ and sessions 1 and 3 (+1.6, 7.8 vs 9.4) yielded significant differences $(Z=-2.401, p=.016 ; Z=-2.714, p=.007$, respectively) underscoring that it is precisely the first time they write when they feel less enthusiastic. These results contrast with previous studies (Nitta \& Babba, 2014) that have ascribed detrimental effects on motivation to TR and encourage the integration of TR practices at schools since students seem not to be bored even after three iterations of the same tasks. Adding to this, our previous knowledge that writing the same text three times seems to result in enhanced performance among YLs (Lázaro-Ibarrola \& Hidalgo, 2021).

When both groups are compared the differences are significant at pre and post-task in the three sessions with the only exception of pre-task session 1 . That is, the students in the TRG display higher motivational scores in sessions 2 and 3 and also at post-task in session 1 . The 
statistical values are the following (Session 1 post-task: $U=38 ; p=.035$; session 2 pre-task $\mathrm{U}=37.5$; $\mathrm{p}=.042$, post-task $\mathrm{U}=31.5$; $\mathrm{p}=.015$; session 3 pre-task $\mathrm{U}=12$; $\mathrm{p}=.000$, post-task $\mathrm{U}=19.5 ; \mathrm{p}=.002$ ). The superior scores at post-task in session 1 in the TRG might indicate more positive dispositions towards writing in the TRG vs. the MG. With this caution in mind, when we examine the pre-task dispositions of the students the significant differences in session 2 seem to suggest that rewriting without any feedback (TRG 8.8) is more motivating than comparing to a model (MG 7.6), although motivation is still high in both groups. As for session 3 , the difference between groups is at its maximum (+4, MG 5.1 vs TRG 9.1). The TRG is clearly more motivated towards the task and sustains a high level of task motivation (TRG 9.1). On the contrary, the task motivation of the MG drops very significantly and the level of task motivation cannot be described as high (MG 5.1). In sum, having to write the draft after the model has dropped the motivation of the students while repeating the draft three times has not.

When looking at the individual results, in the MG the decrease in scores when comparing pre-tasks applies to all participants if we compare sessions 1 and 3, with the exception of two participants who maintained the same score: participant 2 in pair 1 maintained a score of 7 and participant 2 in pair 4 maintained a score of 10 . There is clearly more variability in session 2, which illustrates the co-existence of different perceptions of the process of comparison to the model text. In the TRG the pre-task scores remain quite high for all individuals, fluctuating very little from session to session and never lower in session 3 when compared to session 1 . When comparing post-tasks, the students in the MG chose much lower scores in their third attempt with only two exceptions: student 1 in pair 1, who maintained a score of 9 across tasks and student 2 in pair 4, who maintained a score of 10. In the TRG, as was the case for the pre-task scores, the individual trajectories reflect greater stability with the highest scores in session 3, with 9 students scoring the task with 10 points and 2 students with 9 points. There is, however, one exception in pair 1 where student 1 provided a much lower score, namely, her score was 3 whereas it had been 8 and 9 in the previous sessions' post-task thermometers. When looking at the motives, this participant, in session 3, chose the motive "I got bored" while in the two previous sessions she had chosen a motive connected to her perceptions of collaboration ("I liked to work with my classmate"). Interestingly, as was the case when comparing fluctuations between pre and post-task, none of the exceptions to the tendency applies to the two members of each pair, suggesting that, occasionally, individual trajectories might differ greatly not only within the group but also within the same pair.

To complete these results, Table 2 features the motives that students gave at the end of each session in both groups (third research question). They are presented in terms of percentages and showing the number of students who chose each of the motives. 
Table 2. Mentions and percentages (\%) of motivation reasons selected at post-task in the three sessions.

\begin{tabular}{|c|c|c|c|c|c|c|}
\hline MOTIVES & \multicolumn{2}{|c|}{ SESSION 1} & \multicolumn{2}{|c|}{ SESSION 2} & \multicolumn{2}{|c|}{ SESSION 3} \\
\hline Because I... & MG & TRG & MG & TRG & MG & TRG \\
\hline $\begin{array}{l}\text { I've enjoyed working with my } \\
\text { peer }\end{array}$ & $\begin{array}{c}8 \\
(66.7 \%)\end{array}$ & $\begin{array}{c}13 \\
(92.9 \%)\end{array}$ & $\begin{array}{c}3 \\
(25 \%)\end{array}$ & $\begin{array}{c}7 \\
(58.33 \%)\end{array}$ & $\begin{array}{c}7 \\
(58.3 \%)\end{array}$ & $\begin{array}{c}6 \\
(50 \%)\end{array}$ \\
\hline I have learnt & $\begin{array}{c}2 \\
(16.7 \%)\end{array}$ & & $\begin{array}{c}6 \\
(50 \%)\end{array}$ & $\begin{array}{c}1 \\
(8.3 \%)\end{array}$ & & $\begin{array}{c}2 \\
(16.67 \%)\end{array}$ \\
\hline I liked the task & $\begin{array}{c}1 \\
(8.3 \%)\end{array}$ & & & $\begin{array}{c}1 \\
(8.3 \%)\end{array}$ & & \\
\hline The task was easy & & $\begin{array}{c}1 \\
(8.3 \%)\end{array}$ & & $\begin{array}{c}3 \\
(25 \%)\end{array}$ & & $\begin{array}{c}3 \\
(25 \%)\end{array}$ \\
\hline I've enjoyed it. & $\begin{array}{c}1 \\
(8.3 \%)\end{array}$ & & $\begin{array}{c}1 \\
(8.33 \%)\end{array}$ & & & \\
\hline I'd rather work alone & & & $\begin{array}{c}1 \\
(8.33 \%)\end{array}$ & & $\begin{array}{c}1 \\
(8.3 \%)\end{array}$ & \\
\hline I didn't like the task & & & & & $\begin{array}{c}2 \\
(16.7 \%)\end{array}$ & \\
\hline I had fun doing the task & & & $\begin{array}{c}1 \\
(8.33 \%)\end{array}$ & & $\begin{array}{c}1 \\
(8.3 \%)\end{array}$ & \\
\hline I liked doing a task in English & & & & & $\begin{array}{c}1 \\
(8.3 \%)\end{array}$ & \\
\hline I got bored & & & & & & $\begin{array}{c}1 \\
(8.3 \%)\end{array}$ \\
\hline
\end{tabular}

As Table 2 shows, in session 1, when both groups are writing the composition for the first time, working with peers stands out as the main reason for the scores given, with 8 students choosing this reason in the MG and 13 (all except 1) in the TRG. This leaves all other motives as marginal with only 1 or 2 students choosing them. Also, no student chose "I'd rather work alone" to justify their scores reinforcing the value of peer work as a motivating force. Therefore, in this session, it seems that working together explains the rise in motivation levels in both groups (from 7.7 to 8.6 in the MG and from 7.8 to 9.5 in the TRG) over any other aspect.

In session 2, in which students in the MG were comparing their original composition to a model text while students in the TRG were simply writing the same composition, the differences between groups are clear. In the MG only 3 students highlight the fact that they liked working with their peers in contrast with the 8 students from this group who had chosen 
this option in session 1. Now, 6 students have preferred the positive option in the category of perceived learning opportunities ("I have learnt"), which suggests that these YLs learners understand that comparing their drafts with the model offers them learning opportunities. Clearly, students in the MG are choosing this reason quite frequently compared to the TRG where, again, the main reason for their positive scores is related to the category of enjoyment in relation to the collaboration ( $n=7)$. In addition, it is also interesting to point out that three students have underlined a motive related to the category of task difficulty expressing that 'the task was easy', which reflects the value of task repetition as a facilitating tool to free learners' mental effort (Bui et al., 2018; Bygate, 1996; Bygate \& Samuda, 2005) so that they are able to focus on the language and, ultimately, improve their draft. From a wider SLA perspective, the students' awareness of the learning potential or difficulty of the tasks also highlights that, in spite of their younger age, they are aware of these aspects (Muñoz, 2014).

In session 3, students in the MG rewrote their initial composition trying to incorporate features from the models they examined in session 2. On the other hand, students in the TRG repeated their writing a third time. Working with a peer was their most frequent choice (7 MG and 6 TRG). From the remaining reasons, in the MG, 2 students also chose a negative reason stating that they did not like the task. In the TRG, 1 student also chose a negative reason stating that "she got bored". Also, in the TRG, 3 students (one more than in the previous session) said that the task was easy and 2 stated that "they have learnt". In the MG, as in session 2, 1 student chose the reason "I'd rather work alone". Finally, 1 student chose "I had fun doing the task" and 1 "I liked doing the task in English".

Looking at the scores and motives, the TRG maintains the motivation levels high and working with peers as their main reason although with the repetitions they also select reasons connected to task difficulty. In the MG, while peer work is also the most frequent reason, in session 2 the students also emphasize that they learnt, therefore, even if the motivation is lower perhaps the learning opportunities are higher. In session 3 the drop in motivation is dramatic but only 2 students provided a negative reason ("I didn't like the task"), which makes it hard to explain their motivation decline. Perhaps they thought it was difficult to incorporate the features they had noticed a week earlier or they felt that the model was so good that they could not write a composition of similar quality. Clearly, more research studies are needed to learn about the impact of models or other WCF strategies on task motivation.

When connecting our results with previous research it is clear that we confirm the upward shift at post-task already identified in other students also working in pairs (Azkarai \& Kopinska, 2020; Kopinska \& Azkarai, 2020), as well as a very clear preference towards working with their peers. In our study the pairs were made taking into account their proficiency and interpersonal relationships and, therefore, our study coincides with previous findings (Imaz Agirre \& García Mayo, 2020). 
On the other hand, the fact that 6 students in the MG (50\% of the students in the group) have explained that they learn with the task in the session when they compare their draft to the model seems to reinforce the learning potential of models for these children. The learning potential of TR should also be considered, as 2 students in the third repetition highlight that they have learnt and 3 explain that the task was easy, which connects with the core value of TR as offering the possibility to free attentional resources (Bui et al., 2018; Bygate, 1996; Bygate $\&$ Samuda, 2005). In any case, the high levels of motivation sustained in this group clearly contradict the idea that same task repetition will be perceived as boring by the students (Nitta $\&$ Baba, 2014), at least with three repetitions in collaboration it has not been the case.

\section{CONCLUSIONS}

The present study set off to investigate the motivation that YLs of English working collaboratively display towards two three-stage writing tasks: task repetition and provision of model texts.

Our results show that, in general, task motivation was high, increased at post-task and students' most frequent motive to justify their dispositions was connected to their feelings about collaboration, that is, they enjoyed working with their peers. However, while task motivation was maintained in the TRG, it dropped significantly in the last session in the MG, suggesting that the use of models, unlike the mere repetition of a draft, had had a discouraging effect on the students. In Manchón's (2014a) terms we could say that, in our study, external TR with WCF in the form of model texts has been less positive in terms of motivation than mere TR. More specifically, in the MG students maintained high levels of motivation in sessions 1 and 2 . In contrast, their task motivation significantly decreased to moderate levels when they had to rewrite their initial draft trying to incorporate the features noticed from the model in the third session (pre-task 5.1; post-task 6.6). However, in the session when students were comparing their initial draft to the models their motivation fluctuated but was still high (pre-task 7.6; post-task 8.2), and they selected the positive reason connected to the category of perceived learning opportunities ("we have learnt") $50 \%$ of the time. Yet, our results have to be taken with caution given that, in our study, the TRG obtained superior scores at post-task in session 1, which suggests that, perhaps, their dispositions towards writing were more positive than in the other group. This limitation encourages more research with larger numbers of participants in order to control the variables in a more rigorous way.

When we looked at the results for the pairs and at their individual trajectories we found that most of them followed the general trends with some minor fluctuations, greater in the MG. Nevertheless, we also identified several divergent individual trajectories that did not go in line with the group trend and did not match the trajectory of the other member of the pair (unlike 
in Azkarai \& Kopinska, 2020). This illustrates the dynamic nature of motivation and also its individual nature and constitutes a call for deeper examinations of individual trajectories within pairs to see how these contribute to co-construct a pair motivational dynamic and, also, how individual trajectories interact with learner internal variables, such interactional patterns (Azkarai \& Kopinska, 2020) or engagement levels (Kopinska \& Azkarai, 2020).

All in all, our results clearly encourage the inclusion of further measures of task motivation in research with external TR accompanied by WCF via model texts. For instance, guided interviews could help to get deeper and richer insights into students' dispositions.

In any case, the most striking finding of our study is the high and stable motivational disposition of the students in the TRG. Repeating the same draft three times is not demotivating for them. This could constitute an invitation to introduce the repetition of the same composition in the YL's classroom, as it would save teachers' time, maintain students' motivation and, according to previous studies on the value of TR, enhance learning opportunities. Along these lines, studies on TR should also include measures of task motivation to see if the trend identified in our young pairs is similar in the case of other populations and/or with other tasks and/or with a greater number of repetitions. In sum, more research investigating the characteristics and effects of external TR with and without WCF and including motivation is needed.

Also, a clear finding has been that students repeatedly choose working in pairs as the motive for their high scores. It would be of great interest to conduct further research with students working through similar tasks in pairs and individually to investigate if peer work per se can be the trigger to get students engaged (Kormos \& Dörnyei, 2004). In line with this, researching the pair dynamics in different types of pairs (teacher-selected vs. self-selected; expert vs. novice; etc.) (Imaz Aguirre \& García Mayo, 2020) could contribute to refine our understanding of the construct of motivation when measured in collaborative tasks. In light of our results, researchers and practitioners could get valuable information regarding pair work with YLs in the context of writing tasks, which are usually conducted individually (Storch, 2005). On the other hand, very few students chose the reason 'I'd rather work alone', which reinforces the value of peer work but it also constitutes an important reminder for teachers: some students might not feel comfortable either working in pairs in general or working with a specific peer. Teachers could alternate peers in collaborative activities or occasionally let students choose whether they want to work individually or in pairs to cater for the needs of all the students.

In line with this, we also see from the variety of choices that students make and from some divergent individual trajectories that what moves these students is dynamic and changes from task to task, from pre to post-task, and from student to student (Al Khalil, 2011, 2016; Ushioda, 2001). This should encourage researchers to include measures of task motivation and 
even to follow the trajectories of individuals matching their motivation scores and motives with their achievements. All in all, this points to the need to conduct a more qualitative analysis of students' behaviours.

Finally, supporting Dörnyei and Kormos' (2000) integrated approach to task-based research, we believe that our study provides evidence in favour of introducing task motivation as a measure in task-based research so that the efficiency of a task can be studied in a more holistic and integrated manner. Further research has the challenge to examine the connection between outcomes and task motivation. Perhaps this is a step to take in other areas of SLA too, instead of focusing on one single aspect through a narrow lens our lens should zoom out to get the widest possible view of the array of elements that are having their say in the learning process.

\section{ACKNOWLEDGEMENTS}

This work was supported by the Spanish Ministry of Economy and Competitiveness (MINECO) under grant FFI2016-74950-P (AEI/FEDER/UE) and by the Government of Navarre (Spain) under grant (CENEDUCA18). We would also like to thank the teachers and children for their willingness and generosity to participate in this project.

\section{REFERENCES}

Al Khalil, M.K. (2011). Second language motivation: its relationship to noticing, affect, and production in task-based interaction. Unpublished doctoral dissertation, Georgetown University, USA.

Al Khalil, M. K. (2016). Insights from measurement of task-related motivation. In A. Mackey \& E. Marsden (Eds.), Advancing Methodology and Practice: The IRIS Repository of Instruments for Research into Second Languages (pp. 243-262). New York \& London: Routledge.

Amelohina, V., Nicolás-Conesa, F., \& Manchón, R. M. (2020). Effects of task repetition with the aid of direct and indirect written corrective feedback. In R. Manchón (Ed.), Writing and Language Learning: Advancing Research Agendas (pp. 145-182). Amsterdam: John Benjamins.

Amiryousefi, M. (2016). Homework: Voices from EFL teachers and learners. Iranian Journal of Language Teaching Research, 4(2), 35-54. https://dx.doi.org/10.30466/ijltr.2016.20364

Azkarai A. \& García Mayo, M. P. (2016). Task repetition effects on L1 use in EFL child task-based interaction. Language Teaching Research, 21(4), 480-495. https://dx.doi:10.1177/1362168816654169

Azkarai, A. \& Kopinska, M. (2020). Young EFL learners and collaborative writing: a study on patterns of interaction, engagement in LREs, and task motivation. System, 94, 102338. https://doi.org/10.1016/j.system.2020.102338

Bui, G., Ahmadian, M. J., \& Hunter, A.-M. (2018). Spacing effects on repeated L2 task performance. System, 81, 1-13. https://doi.org/10.1016/j.system.2018.12.006. 
Bygate, M. (1996). Effects of task repetition: Appraising the developing language of learners. In J. Willis \& D. Willis (Eds.), Challenge and change in Language Teaching (pp. 136-146). Oxford: Macmillan Heinemann.

Bygate, M. \& Samuda, V. (2005). Integrative planning through the use of task repetition. In R. Ellis (Ed.), Planning and Task Performance in a Second Language (pp. 37-74). Amsterdam: John Benjamins.

Calzada, A. \& García Mayo, M. P. (2020). Child EFL learners' attitudes towards a collaborative writing task: An exploratory study. Language Teaching for Young Learners, 2(1), 52-72. https://doi.org/10.1075/ltyl.19008.cal

Cánovas Guirao, J., Roca de Larios, J., \& Coyle, Y. (2015). The use of models as a written feedback technique with young EFL learners. System, 52, 63-77. https://doi.org/10.1016/j.system.2015.04.002

Coyle, Y. \& Cánovas Guirao, J. (2019). Learning to write in a second language: The role of guided interaction in promoting children's noticing from model texts. CLIL Journal of Innovation and Research in Plurilingual and Pluricultural Education, 1(2), 21-30.

Coyle, Y. \& Roca de Larios, J. (2014). Exploring the role played by error correction and models on children's reported noticing and output production in a L2 writing task. Studies in Second Language Acquisition, 36, 451-485. https://dx.doi:10.1017/S0272263113000612

Coyle, Y. \& Roca de Larios, J. (2020). Exploring young learners' engagement with models as a written corrective technique in EFL and CLIL settings. System, 95, 102374. https://doi.org/10.1016/j.system.2020.102374

Coyle, Y., Cánovas Guirao, J., \& Roca de Larios, J. (2018). Identifying the trajectories of young EFL learners across multi-stage writing and feedback processing tasks with model texts. Journal of second language writing, 42, 25-43.

Dörnyei, Z. (2002). The motivational basis of language learning tasks. In P. Robinson (Ed.), Individual Differences and Instructed Language Learning (pp. 137-158). Amsterdam: John Benjamins. Reprinted in: K. Van den Branden, M. Bygate, \& J. M. Norris (Eds.), Task-Based Language Teaching: A Reader (pp. 357-377). Amsterdam: John Benjamins.

Dörnyei, Z. (2009). The Psychology of Second Language Acquisition. Oxford: Oxford University Press. Dörnyei, Z. (2019). What makes an L2 task engaging? In E. Zhisheng \& M. J. Ahmadian (Eds.), Researching L2 Task Performance and Pedagogy: In Honour of Peter Skehan (pp. 53-66). Amsterdam: John Benjamins.

Dörnyei, Z. (2020). From integrative motivation to directed motivational currents: The evolution of the understanding of L2 motivation over three decades. In M. Lamb, K. Csizér, A. Henry, \& S. Ryan (Eds.), Palgrave Macmillan Handbook of Motivation for Language Learning (pp. 39-69). Basingstoke: Palgrave.

Dörnyei, Z. \& Kormos, J. (2000). The role of individual and social variables in oral task performance. Language Teaching Research, 4(3), 275-300. https://doi.org/10.1177/136216880000400305

Ellis, R. (2009). The differential effects of three types of task planning on the fluency, complexity, and accuracy in L2 oral production. Applied Linguistics, 30, 474-509. http://dx.doi.org/10.1093/applin/amp042

Enever, J. (2018). Policy and Politics in Global Primary English. Oxford: Oxford University Press.

(c) Servicio de Publicaciones. Universidad de Murcia. All rights reserved. IJES, vol. 21(2), 2021, pp. 29-55 Print ISSN: 1578-7044; Online ISSN: 1989-6131 
Fernández Dobao, A. (2012). Collaborative writing tasks in the L2 classroom: Comparing group, pair, and individual work. Journal of Second Language Writing, 21(1), 40-58. https://doi.org/10.1016/j.jslw.2011.12.002

Ferris, D. \& Hedgcock, J. (2014). Teaching L2 Composition. Purpose, Process, and Practice. (3rd ed.). New York/London: Routledge/Taylor \& Francis.

García Mayo, M. P. (2018). Child task-supported interaction in the Spanish EFL setting. Research and challenges. International journal of English studies, 18(2), 119-143. https://doi.org/10.6018/ijes/2018/2/319731

García Mayo, M. P. \& Loidi Labandibar, U. (2017). The Use of Models as Written Corrective Feedback in English as a Foreign Language (EFL)Writing. Annual Review of Applied Linguistics, 37, 110-127. https://doi.org/10.1017/S0267190517000071

Hanaoka, O. (2007). Output, noticing, and learning: An investigation into the role of spontaneous attention to form in a four-stage writing task. Language Teaching Research, 11(4), 459-479. https://doi.org/10.1177/1362168807080963.

Hanaoka, O. \& Izumi, S. (2012). Noticing and uptake: Addressing pre-articulated covert problems in L2 writing. Journal of Second Language Writing, 21(4), 332-347. http://dx.doi.org/10.1016/j.jslw.2012.09.008

Hawkes, M.L. (2009). Effects of Task Repetition on Learner Motivation. In A.M. Stoke (Ed.), JALT2009 Conference Proceedings (pp. 456-465). Tokyo: JALT.

Hidalgo, M. Á. \& Lázaro-Ibarrola, A. (2020). Task repetition and collaborative writing by EFL children: Beyond CAF measures. Studies in Second Language Learning and Teaching, 10(3), 501522. https://doi.org/10.14746/ssllt.2020.10.3.5

Imaz Agirre, A. \& García Mayo, M.P. (2020). The impact of agency in pair formation on the degree of participation in young learners' collaborative dialogue. In C. Lambert \& R. Oliver (Eds.), Using Tasks in Second Language Teaching: Practice in Diverse Contexts (pp. 306-323). Clevedon: Multilingual Matters.

Julkunen, K. (2001). Situation- and task-specific motivation in foreign language learning. In Z.

Dörnyei \& R. Schmidt (Eds.), Motivation and Second Language Acquisition (pp. 29-42).

Honolulu, HI: University of Hawaii Press.

Kang, E. Y. (2020). Using model texts as a form of feedback in L2 writing. System, 89, 102196. https://doi.org/10.1016/j.system.2019.102196

Kim, J. H. (2015). The role of models and error correction in L2 young learners' noticing and output. English Teaching, 70(2), 3-26. https://doi.org/10.15858/engtea.70.2.201506.3

Kim, J. \& Nassaji, H. (2018). Incidental focus on form and the role of learner extraversion. Language Teaching Research, 22(6), 698-718. https://doi.org/10.1177\%2F1362168817699642

Kim, Y., Choi, B., Yun, H., Kim, B. \& Choi, S. (2020). Task repetition, synchronous written corrective feedback and the learning of Korean grammar: A classroom-based study. Language Teaching Research. https://doi.org/10.1177\%2F1362168820912354

Kim, Y., Kang, S., Yun, H., Kim, B., \& Choi, B. (2020). The role of task repetition in a Korean as a foreign language classroom: Writing quality, attention to form, and learning of Korean grammar. Foreign Language Annals, 53(4), 827-849. https://doi.org/10.1111/flan.12501 
Kiss, C. \& Nikolov, M. (2005). Developing, piloting, and validating an instrument to measure young learners' aptitude. Language Learning, 55(1), 99-150. https://doi.org/10.1111/j.00238333.2005.00291.x

Kopinska, M. \& Azkarai, A. (2020). Exploring young EFL learners' motivation: Individual versus pair work on dictogloss tasks. Studies in Second Language Learning and Teaching, 10(3), 607-630. https://doi.org/10.14746/ssllt.2020.10.3.10

Kormos, J. \& Dörnyei, Z. (2004). The interaction of linguistic and motivational variables in second language task performance. Zeitschrift für interkulturellen Fremdsprachenunterricht, 9(2), 19.

Lázaro-Ibarrola, A. (2021). Model texts in collaborative and individual writing among EFL children: noticing, incorporations, and draft quality. International Review of Applied Linguistics in Language Teaching, 000010151520200160. https://doi.org/10.1515/iral-2020-0160

Lázaro-Ibarrola, A. \& Hidalgo, M. Á. (2021). Give me a second chance: Task repetition and collaborative writing with child EFL learners. Language Teaching for Young Learners, 3(2), 275-299. https://doi.org/10.1075/ltyl.20009.laz

Lázaro-Ibarrola, A. \& Hidalgo, M. Á. (2017). Procedural repetition in task-based interaction among young EFL learners: Does it make a difference? ITL-International Journal of Applied Linguistics, 168(2), 183-202. http://dx.doi.org/10.1075/itl.16024.laz

Luquin, M. \& García Mayo, M. P. (2020). Collaborative writing and feedback: An exploratory study of the potential of models in primary EFL students' writing performance. Language Teaching for Young Learners, 2(1), 73-100. https://doi.org/10.1075/ltyl.19007.luq

Luquin, M. \& García Mayo, M. P. (2021). Exploring the use of models as a written corrective feedback technique among EFL children. System, 98. https://doi.org/10.1016/j.system.2021.102465

McCargar, D. F. (1993). Teacher and student role expec-tations: Cross-cultural differences and implications. Modern Language Journal, 77(2), 192-207. https://doi.org/10.1111/j.15404781.1993.tb01963.x

MacIntyre, P. D. \& Serroul, A. (2014). Motivation on a per-second timescale: Examining approachavoidance motivation during L2 task performance. In M. Kruk \& M. Mahmoodzadeh (Eds.), Motivational Dynamics in Language Learning (pp. 109-138). Clevedon: Multilingual Matters. https://doi.org/10.21832/9781783092574-013

Manchón, R. M. (2014a). The distinctive nature of task repetition in writing. Implications for theory, research, and pedagogy. Estudios de Lingüística Inglesa Aplicada ELIA, 14(13), 13-41. http://dx.doi.org/10.12795/elia.2014.i14.02

Manchón, R. M. (2014b). The internal dimension of tasks. In H. Byrnes \& R. M. Manchón (Eds.), Task-Based Language Learning: Insights from and for L2 Writing (pp. 27-52). Amsterdam: John Benjamins Publishing Company. https://doi.org/10.1075/tblt.7.02man

Muñoz, C. (2014). Exploring Young Learners' Foreign Language Learning Awareness. Language Awareness, 23(1-2), 24-40. https://doi.org/10.1080/09658416.2013

Muñoz, C. (2017). The development of language awareness at the transition from primary to secondary school. In M. P. García Mayo (Ed.), Learning Foreign Languages in Primary School: Research Insights (pp. 49-68). Bristol: Multilingual Matters. 
Nikolov, M. (1999). 'Why do you learn English?' 'Because the teacher is short.' A study of Hungarian children's foreign language learning motivation. Language Teaching Research, 3(1), 33-56. http://dx.doi.org/10.1191/136216899670790538

Nitta, R. \& Baba, K. (2014). Task repetition and L2 writing development. In R. Manchón \& H. Byrnes, (Eds.), Task-Based Language Learning: Insights from and for L2 Writing (pp. 107-136). Amsterdam: John Benjamins.

Poupore. (2013). Task motivation in process: A complex systems perspective. The Canadian modern language review/La Revue canadienne des langues vivantes, 69(1), 91-116 http://dx.doi:10.3138/cmlr.1139

Robinson, P. (2011). Task-based language learning: A review of issues. Language Learning, 61(1), 136. http://dx.doi.org/10.1111/j.1467-9922.2011.00641.x

Samuda, V. \& Bygate, M. (2008). Tasks in Second Language Learning. Basingstoke: Palgrave Macmillan.

Sánchez, A. J. (2018). External task-repetition: The role of modality, written corrective feedback and proficiency: A comparative study. Unpublished doctoral dissertation, University of Murcia, Spain.

Sánchez, A. J., Manchón, R. M., \& Gilabert, R. (2020). The effects of task repetition across modalities and proficiency levels. In R. Manchón (Ed.), Writing and Language Learning: Advancing Research Agendas (pp. 121-144). Amsterdam: John Benjamins.

Schulz, R. A. (2001). Cultural differences in student and teacher perceptions concerning the role of grammar instruction and corrective feedback: USA-Colombia. The Modern Language Journal, 85(2), 244-258.

Storch, N. (2013). Collaborative Writing in L2 Classrooms (Vol. 31). Clevedon: Multilingual Matters.

Storch, N. (2011). Collaborative writing in L2 contexts: Processes, outcomes, and future directions.

Annual Review of Applied Linguistics, 31, 275-288.
https://doi.org/10.1017/S0267190511000079

Storch, N. (2005). Collaborative writing: Product, process, and students' reflections. Journal of Second Language Writing, 14(3), 153-173. https://doi.org/10.1016/j.jslw.2005.05.002

Storch, N. (1999) Are two heads better than one? Pair work and grammatical accuracy. System, 27, 363-74. https://doi.org/10.1016/S0346-251X(99)00031-7

Ushioda, E. (2001). Language learning at university: Exploring the role of motivational thinking. In Z. Dörnyei \& R. W. Schmidt (Eds.), Motivation and Second Language Acquisition (pp. 93-125). Honolulu, HI: University of Hawaii, Second Language Teaching Center.

Villarreal, I. \& Munarriz-Ibarrola, M. (2021). "Together we do better": The effect of pair and group work on young EFL learners' written texts and attitudes. In M. P. García Mayo (Ed.), Working Collaboratively in Second/Foreign Language Learning (pp. 89-116). Boston/Berlin: De Gruyter Mouton.

Wigglesworth, G. \& Storch, N. (2009). Pair versus individual writing: Effects on fluency, complexity and accuracy. Language Testing, 26(3), 445-466. https://doi.org/10.1177/0265532209104670

Yang, L. \& Zhang, L. (2010). Exploring the role of reformulations and a model text in EFL students' writing performance. Language Teaching Research, 14(4), 464-484. https://doi.org/10.1177\%2F1362168810375369

(C) Servicio de Publicaciones. Universidad de Murcia. All rights reserved. IJES, vol. 21(2), 2021, pp. 29-55 Print ISSN: 1578-7044; Online ISSN: 1989-6131 


\section{APPENDICES}

APPENDIX A. PRE-TASK AND POST-TASK MOTIVATION THERMOMETER

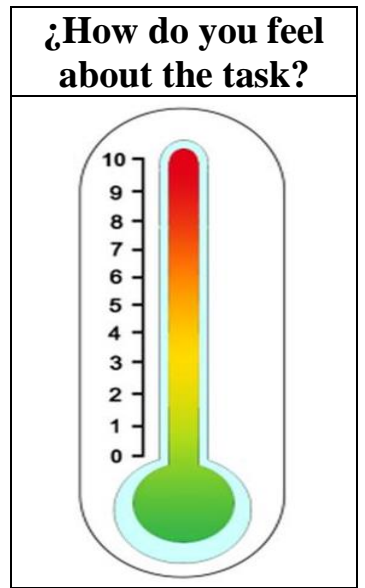

APPENDIX B. THE POST-TASK LIST OF MOTIVES AND CORRESPONDING CATEGORIES (KIM, CHOI ET AL. (2020)

\begin{tabular}{|c|c|c|}
\hline & Categories & Why did you choose your score \\
\hline \multirow{2}{*}{\multicolumn{2}{|c|}{ Perceived task difficulty }} & Because the task was easy. \\
\hline & & Because the task was difficult. \\
\hline \multirow{2}{*}{\multicolumn{2}{|c|}{ Perceived learning opportunities }} & Because I have learnt. \\
\hline & & Because I haven't learnt. \\
\hline \multirow{7}{*}{ Enjoyment } & General & Because I got bored. \\
\hline & \multirow{2}{*}{$\begin{array}{r}\text { In relation to } \\
\text { the task }\end{array}$} & Because I enjoyed doing the task. \\
\hline & & Because I didn't like the task. \\
\hline & \multirow{2}{*}{$\begin{array}{r}\text { In relation to } \\
\text { doing a task } \\
\text { in a foreign } \\
\text { language }\end{array}$} & Because I liked to do a task in English. \\
\hline & & $\begin{array}{l}\text { Because I didn't like to do a task in } \\
\text { English. }\end{array}$ \\
\hline & \multirow{2}{*}{$\begin{array}{l}\text { In relation to } \\
\text { collaboration } \\
\text { (with a peer) }\end{array}$} & $\begin{array}{l}\text { Because I liked to work with my } \\
\text { classmate. }\end{array}$ \\
\hline & & $\begin{array}{l}\text { Because I didn't like to work with my } \\
\text { classmate. }\end{array}$ \\
\hline
\end{tabular}




\section{APPENDIX C. PICTURE PROMPT AND MODEL TEXTS}
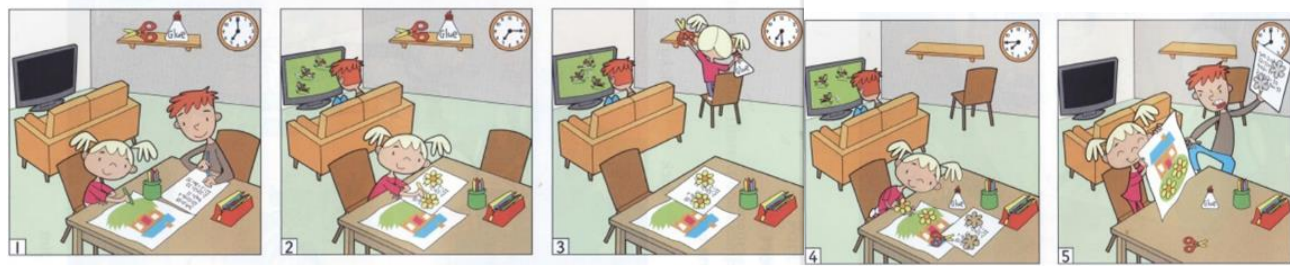

Source. From Cambridge English. (2014). Young Learners. Young Learners English Tests

(YLE). Sample Papers. Flyers. Practice Test 3. Cambridge University Press, p. 3.

\section{Model A}

It's Monday evening and Tom is doing his homework while his sister Katie does some drawing. After a while, Tom gets bored and decides to watch the football on TV. Katie has drawn a lovely house with a garden but she wants to put some flowers on the grass. She sees Tom's homework and starts to draw flowers on it.

Soon Katie's flowers are finished so she gets some scissors and glue, cuts them out and sticks them onto her picture. Proud of her work, Katie shows her picture to her brother. When Tom realises where the flowers have come from and sees his ruined homework, he is furious!

\section{Model B}

Tom and Katie are brother and sister and they are in the sitting room of their house. They are sitting at a table. It is 7 o'clock. Tom is doing his homework and Katie is drawing a picture of a house and garden. At 7.15 Tom is watching TV and Katie is drawing another picture of two big flowers. She is drawing the flowers on Tom's piece of paper! At 7.30 she gets the glue and the scissors. At 7.45 she has cut out the two flowers and is sticking them both on the picture of her garden. At 8 O'clock Tom sees what Katie has done and is very angry but she is very happy with her picture. 
APPENDIX D.

Scores per pair and per individual

\begin{tabular}{|c|c|c|c|c|c|c|c|c|}
\hline & & \multirow{2}{*}{\multicolumn{2}{|c|}{ SESSION 1}} & \multirow{2}{*}{\multicolumn{2}{|c|}{ SESSION2 }} & \multirow{2}{*}{\multicolumn{2}{|c|}{ SESSION 3}} \\
\hline & & & & & & & & \\
\hline \multirow{13}{*}{ MG } & PAIR & SUBJECE & PRE & POST & PRE & POST & PRE & POST \\
\hline & P1 & S1 & 9 & 9 & 8 & 9 & 8 & 9 \\
\hline & & $\mathbf{S 2}$ & 7 & 8 & 7 & 7 & 7 & 6 \\
\hline & $\mathbf{P 2}$ & S1 & 6 & 8 & 5 & 8 & 2 & 4 \\
\hline & & S2 & 7 & 8 & 6 & 8 & 3 & 5 \\
\hline & $\mathbf{P 3}$ & S1 & 9 & 9 & 7 & 7 & 5 & 7 \\
\hline & & S2 & 9 & 9 & 9 & 10 & 7 & 7 \\
\hline & $\mathbf{P 4}$ & S1 & 6 & 8 & 8 & 9 & 4 & 6 \\
\hline & & S2 & 10 & 10 & 10 & 10 & 10 & 10 \\
\hline & P5 & S1 & 9 & 10 & 9 & 8 & 4 & 8 \\
\hline & & S2 & 9 & 10 & 8 & 9 & 5 & 7 \\
\hline & P6 & S1 & 6 & 8 & 8 & 8 & 3 & 5 \\
\hline & & S2 & 6 & 7 & 7 & 6 & 4 & 6 \\
\hline \multirow{12}{*}{ TRG } & P7 & S1 & 6 & 9 & 6 & 8 & 7 & 3 \\
\hline & & $\mathbf{S 2}$ & 6 & 8 & 9 & 9 & 8 & 9 \\
\hline & P8 & S1 & 6 & 10 & 8 & 10 & 10 & 10 \\
\hline & & S2 & 8 & 10 & 9 & 9 & 9 & 10 \\
\hline & P9 & S1 & 8 & 10 & 10 & 10 & 10 & 10 \\
\hline & & S2 & 8 & 10 & 9 & 10 & 10 & 10 \\
\hline & P10 & S1 & 7 & 8 & 7 & 8 & 8 & 10 \\
\hline & & S2 & 6 & 9 & 8 & 9 & 8 & 9 \\
\hline & P11 & S1 & 10 & 10 & 10 & 10 & 10 & 10 \\
\hline & & $\mathbf{S 2}$ & 10 & 10 & 10 & 10 & 10 & 10 \\
\hline & P12 & S1 & 9 & 10 & 10 & 10 & 10 & 10 \\
\hline & & S2 & 10 & 10 & 10 & 10 & 10 & 10 \\
\hline
\end{tabular}

(C) Servicio de Publicaciones. Universidad de Murcia. All rights reserved. IJES, vol. 21(2), 2021, pp. 29-55 